\title{
Studies of Sedimentary Facies, Stratigraphy, and Deformation Structures of the Chelungpu Fault Zone on Cores from Drilled Wells in Fengyuan and Nantou, Central Taiwan
}

\author{
Shiuh-Tsann Huang ${ }^{1,2, *}$, Jong-Chang $\mathrm{Wu}^{1,3}$, Jih-Hao Hung ${ }^{2}$, and Hidemi Tanaka ${ }^{4}$
}

(Manuscript received 20 April 2002, in final form 26 August 2002)

\begin{abstract}
Stratigraphy, sedimentary facies, and deformation characteristics of drill cores from Fengyuan and Noutou wells reveal important attributes for the westmost portion of active Chelungpu thrust fault and contrasting deformation mechanisms between the north and south ends.

Stratigraphy of the Fengyuan well (including BH-1 and BH-1A boreholes) is composed of three major units, including the upper Miocene to Pliocene Kueichulin Formation (455.4-224.7 m), the Pliocene Chinshui Shale (224.7-3.9 $\mathrm{m})$ and recent terrace deposits $(3.9-0 \mathrm{~m})$. The Kueichulin Formation comprises three upward coarsening, tide-dominated delta parasequences with sandstone and sandstone-Shale alternations. The Chinshui Shale is dominated by shallow marine facies with siltstone, mudstone and fine-grained sandstone. Shallow marine facies are occasionally intercalated with tide-dominated delta deposits. Terrace deposits are characterized by paleosol, yellowish mud, mottled leaching soil and thin pebble layers. The Chi-Chi earthquake slip zone is located at a transgressive deposit, which is also the sequence boundary between the Kueichulin Formation and the Chinshui Shale. Other two major brecciated shear zones are also the parasequence boundaries within the Kueichulin Formation.

Stratigraphic sequence of the Nantou well (CLF-2) is composed of the Pleistocene Toukoshan Formation (211.9-177 $\mathrm{m}$ ) in the footwall, and the Chinshui Shale (177-8.7 $\mathrm{m}$ ) and terrace deposits $(8.7-0 \mathrm{~m})$ in the hangingwall. The Toukoshan Formation is characterized by alternation of conglomerates and yellowish fine-grained deposits with drifted pebbles, an indication of braided fluvial deposits. The Chinshui Shale comprises alternating shallow marine and tidal deposits. The shallow marine face is dominated
\end{abstract}

\footnotetext{
${ }^{1}$ Exploration and Development Research Institute, Miaoli, Taiwan

${ }^{2}$ Institute of Geophysics, National Central University, Chung Li, Taiwan

${ }^{3}$ Department of Earth Sciences, National Taiwan Normal University, Taipei, Taiwan

${ }^{4}$ Department of Earth Science, University of Tokoyo, Tokoyo Japan

* Corresponding author address: Mr. Shiuh-Tsann Huang, Exploration and Development Research Institute, Chinese Petroleum Corporation, 1 Ta Yuan, Wen Shan, Miaoli, Taiwan, 36010, Taiwan, ROC
} 
by mudstone, siltstone and fine-grained sandstone with moderate to high degree of bioturbation. Terrace deposits are characterized by yellowish gray mud, pebble layer, and mottled paleosol. Overall, shear zones in the Nantou well is characterized by foliated gouge or breccia as opposed to breccia or gouge of random fabrics in the Fengyuan well.

(Key words: Slip zone, Sequence boundary, Breccia and Foliated gouge)

\section{INTRODUCTION}

Two shallow boreholes at Fengyan and Nantou were drilled during 2000 to 2001 in order to study the Chelungpu Fault zone (Fig. 1; Ando et al. 2001). The purposes of these wells are 1) to collect basic data of rupture characteristics and 2) to understand deformation mechanisms which control contrasting amount of slip in the south and north ends of the Chelungpu fault during the Chi-Chi Earthquake. A series of studies in different fields are still in progress, and preliminary results were reported in two international core workshops (Tanaka et al. 2001; Hung et al. 2001). This article attempts to address above questions through integrated analyses

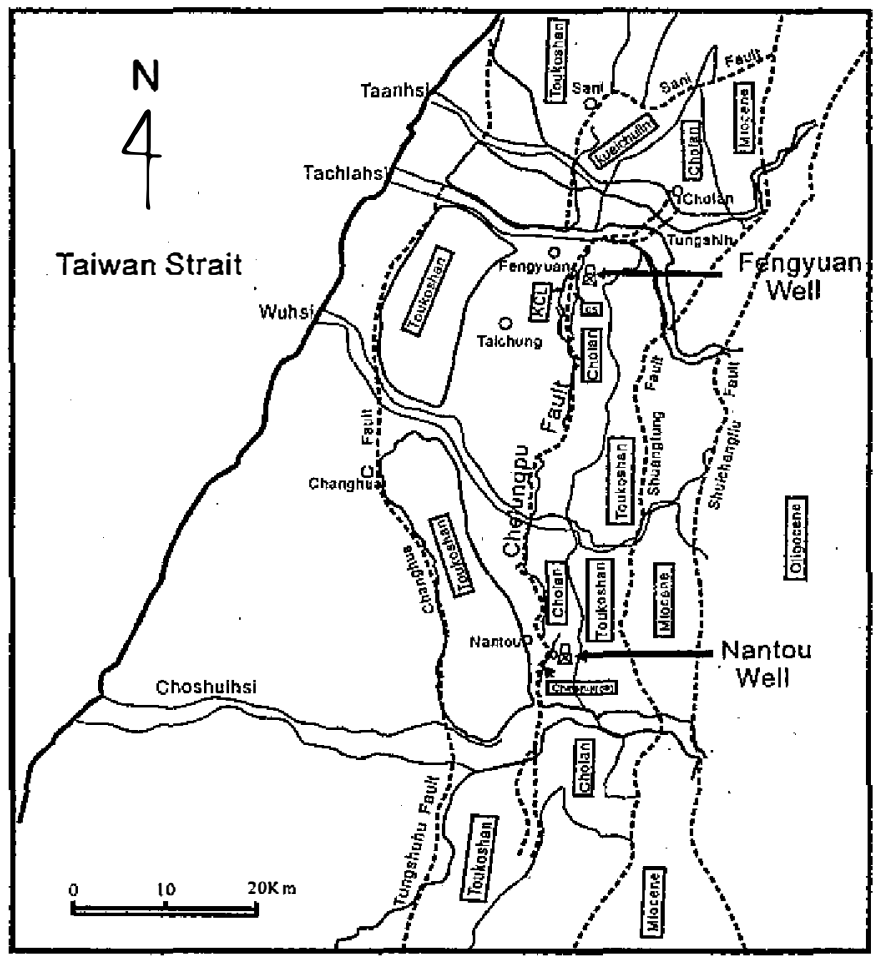

Fig. 1. Locations of Fengyuan and Nantou wells and a generalized geologic map of central Taiwan (modified from Wang et al. 2002). Dash lines are thrust faults; terms in rectangular, formation names. 
of stratigraphy, biostratigraphy, sedimentary facies and deformation fabrics.

Figure 1 shows the well locations with a simplified geologic map. The Fengyuan well is an inclined borehole dipping $50^{\circ}$ towards west (Fig. 2). Seismic reflections indicated that beds dip uniformly toward the east from the surface to the footwall of the Chelungpu Fault. The Nantou well is a vertical borehole, and both well log and seismic profile show the east-dipping layer-parallel Chelungpu Fault cuts across the undisturbed Toukoshan Formation in the footwall.

\section{CORE DESCRIPTION}

Data associated with cores and wells are listed in Table 1. The Fengyuan well is composed of two holes, BH-1 (1-293.4 m) and BH-1A (208-455.35 m). There is an overlap of 85 . 4 meters between these two holes. The Nantou well is a vertical well with total depth of 211.9 meters. Composite core descriptions and exemplified photographs of these two wells are shown from Figs. 3 to 12.

\subsection{Fengyuan Well (BH-1and BH-1A)}

The geological column of BH-1 borehole consists three major stratigraphic units: the Yutenping Sandstone Member (293.4-224.7 m; Upper Kueichulin Formation), the Chinshui Shale (224.7-3.9 m) and terrace deposit (3.9-0 m; Fig. 3). The Yutenping Sandstone is characterized by tide-dominated delta system, which is manifested by following sedimentary features such as wavy and lenticular bedding, herringbone strúcture, transported shell fragments, mud drapes, carbonaceous material, upward coarsening sequence assemblage, and moderate
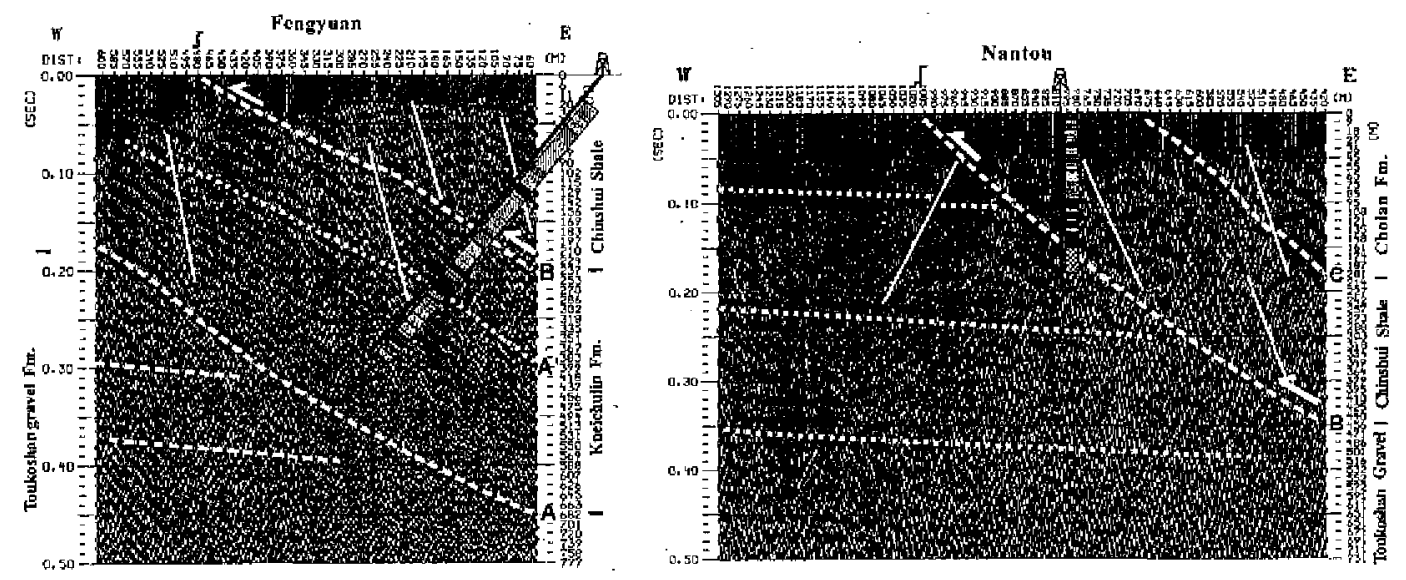

Fig. 2. Seismic reflention profiles across the inclined Fengyuan and vertical Nantou wells (from Wang et al. 2002). Note the Kueichulin Formation at the footwall of the Chelungpu fault dips toward east whereas the Toukoshan Formation is nearly horizontal and only partly distorted in Nantou well. Slash pattern: shale; dots: sandstone; dark area: shear slip zone. 
Table 1. Drilled well data and core description.

\begin{tabular}{|c|c|c|c|c|c|c|}
\hline Site & Well & Box & Length & Depth & Well Direction & Location \\
\hline \multirow{2}{*}{ Fengyuan } & $\begin{array}{c}\text { BH-1 } \\
\text { (first hole) }\end{array}$ & 74 & 293.4 & $1-293.4$ & \multirow{2}{*}{$\begin{array}{c}\text { Inclinal } \\
\operatorname{dip}=50 \sim 47^{\circ}\end{array}$} & \multirow{2}{*}{$\begin{array}{l}120^{\circ} 43^{\prime} 48.90^{\prime \prime} \\
24^{\circ} 14^{\prime} 11.57^{\prime \prime}\end{array}$} \\
\hline & $\begin{array}{c}\text { BH-1A } \\
\text { (second hole) }\end{array}$ & 63 & 248.35 & $208-455.35$ & & \\
\hline $\begin{array}{l}\text { Nantou } \\
\text { (Chenchiu) }\end{array}$ & CLF-2 & 53 & 211.9 & $1-211.9$ & $\begin{array}{l}\text { Vertical } \\
\text { dip }=90^{\circ}\end{array}$ & $\begin{array}{l}120^{\circ} 42^{\prime} 19.19^{\prime \prime} \\
23^{\circ} 53^{\prime} 37.21^{\prime \prime}\end{array}$ \\
\hline Total & & 191 & 753.65 & & & \\
\hline
\end{tabular}

bioturbation. The Chinshui Shale deposits in shallow marine and interclated tidal environments, and contains transported shell fragments and hummochy cross bedding, carbonaceous material and moderate to intense bioturbation. Drilling depth between $130-180 \mathrm{~m}$ is interpreted as deposits in a tidal environment, with similar features that occur in the Yutenping Sandstone. The terrace deposit is characterized by yellowish mud, paleosol, mottled leaching soil and thin pebble layers.

BH-1A borehole is composed of two major stratigraphic units: the Yutenping Sandstone and the Chinshui Shale (Fig. 4). The Yutenping Sandstone consists of three stacking parasequences of tide-dominated delta, in which the prodelta is composed of bioturbated marine mudstone, and the delta front is characterized by upward coarsening deposit assemblages. The delta plain is characterized by coarser grain, with channel scour structures and thin layers of overbank deposits. In the Yutenping Sandstone, lenticular bedding, wavy bedding, flaser bedding, cross bedding, ransported shell fragments, mud drapes, carbonaceous material, moderate and intense bioturbation are major sedimentary features and sometimes interclated with hummocky cross bedding, which has generated by storm deposits. The Chinshui Shale is interpreted as shallow marine facies with current ripples, shell fragments and slight to moderate bioturbation. The boundary between the Yutenping Sandstone and the Chinshui Shale is recognized as a condensed section with a transgressive deposit (Figs 6 and 9). The illustration of detailed core photograph is shown in Fig. 10. The trangressive deposit is composed of 4 unit: 1) well sorted, light gray, loss fine-grained sandstone, 2) white laminated, intensely cemented and well sorted medium grain sandstone with a scour surface and shell fragments and mud drapes, 3) white gray, poorly sorted, very coarse grain sandstone, containing conglomerates of channel deposit with a scour surface and part of calcification feature and 4) laminated mudstone, interpreted as condensed section zone during the stage of stillstand tracks.

\subsection{The Nantou Well (CLF-2)}

The Nantou well comprises three major stratigraphic units: the Toukoshan Formation 
Fengyuan Well(BH-1)

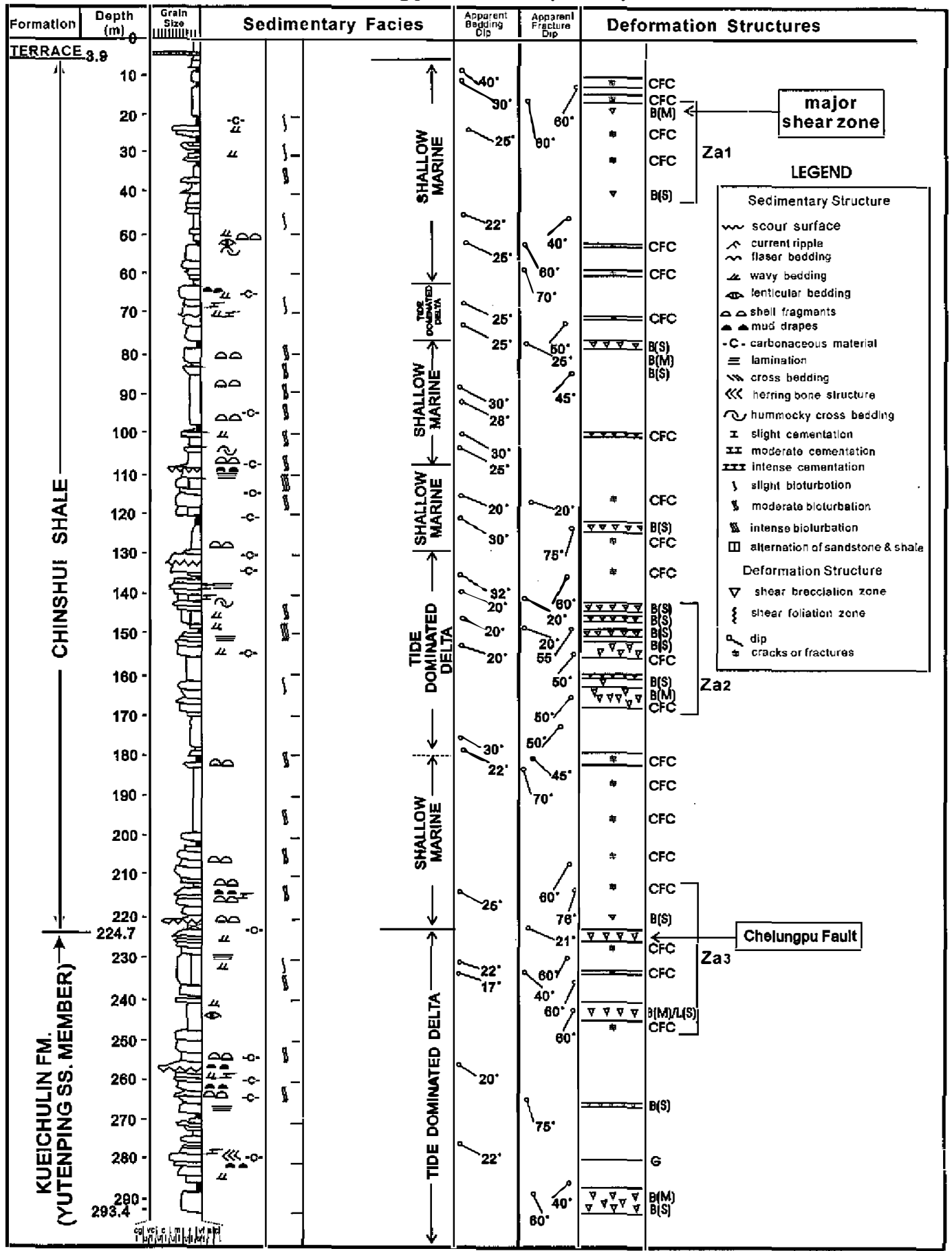

Fig. 3. Geological column of Fengyuan well (BH-1). 
Fengyuan Well(BH-1A)

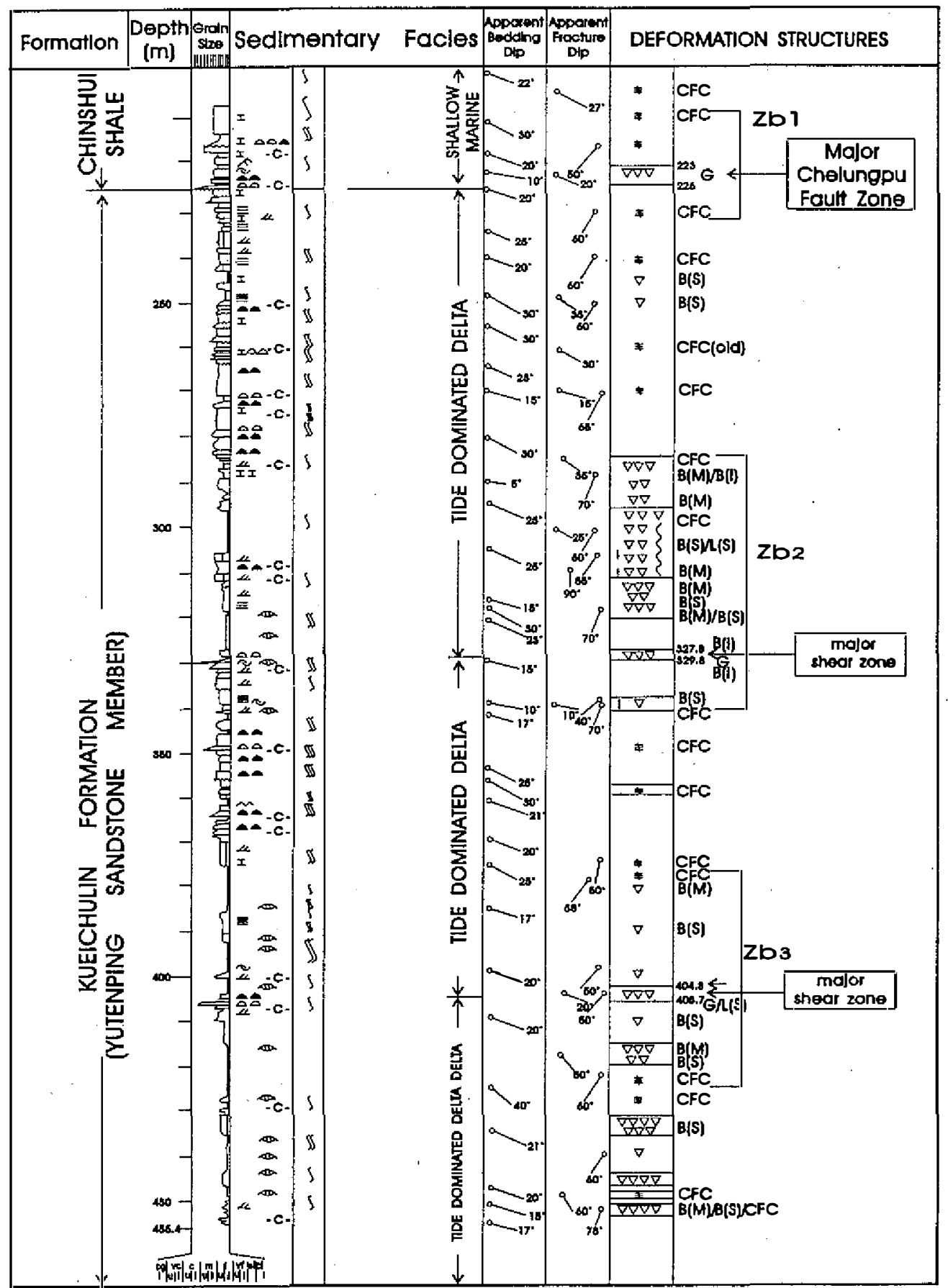

Fig. 4. Geological column of Fengyuan well (BH-1A). 


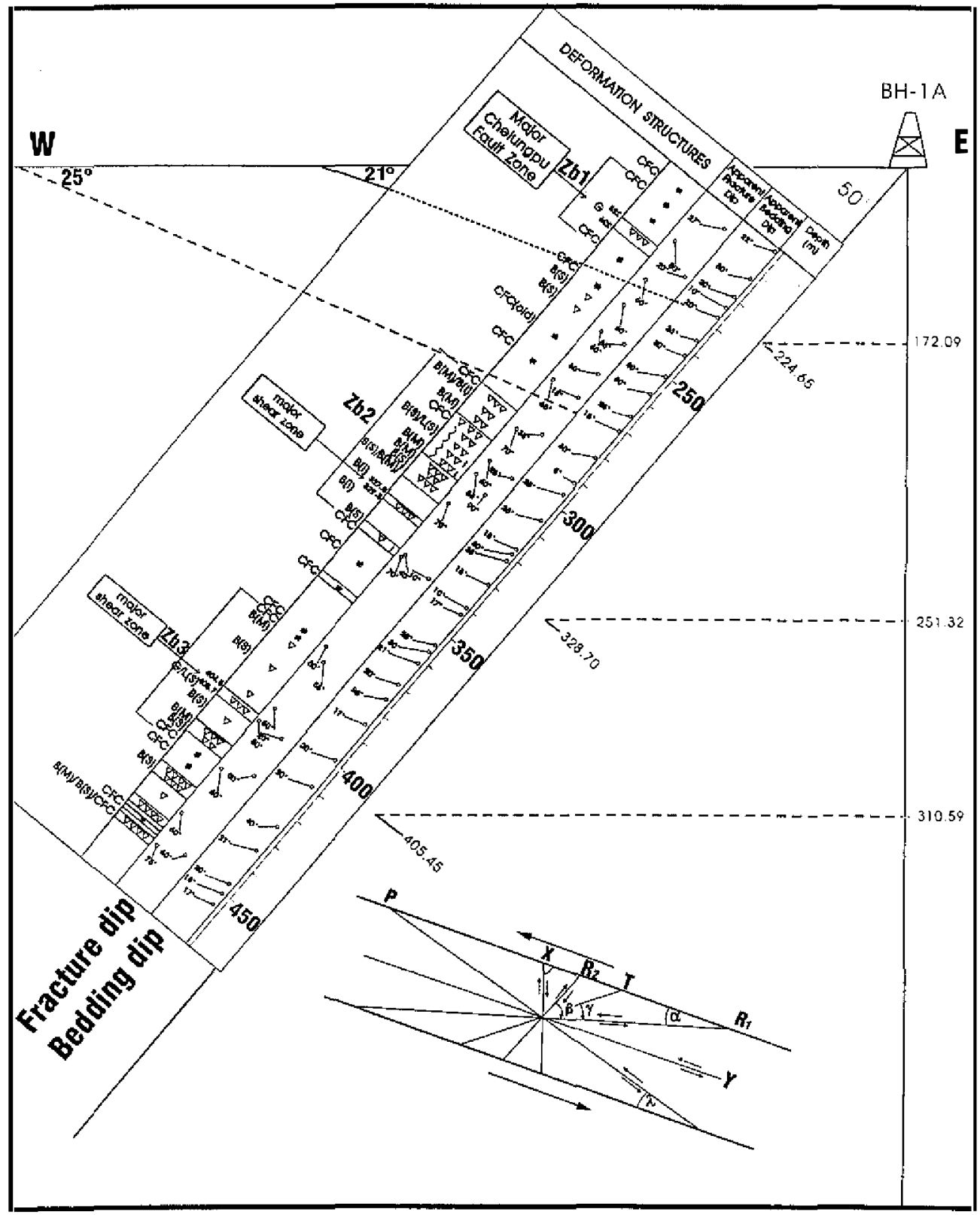

Fig. 5. True dips of bedding and fractures in BH-1A using Ridel shear model.

(211.9-177 $\mathrm{m}$ ), the Chinshui Shale (177-8.7 $\mathrm{m}$ ) and terrace deposit (8.7-0 $\mathrm{m}$ ) (Fig. 11). The Toukoshan Formation is composed of alternation of conglomerate and yellowish mudstone. The conglomerate successions contain small pebbles and sand matrix, whereas mudstone successions contain paleosol, leaching mottled shale, and poorly sorted sandstone (Fig. 12). The Chinshui Shale is composed of mudstone and fine-grained sandstone of low energy deposit at 
BH1-A ( Zb1, Chelungpu Fault Zone)

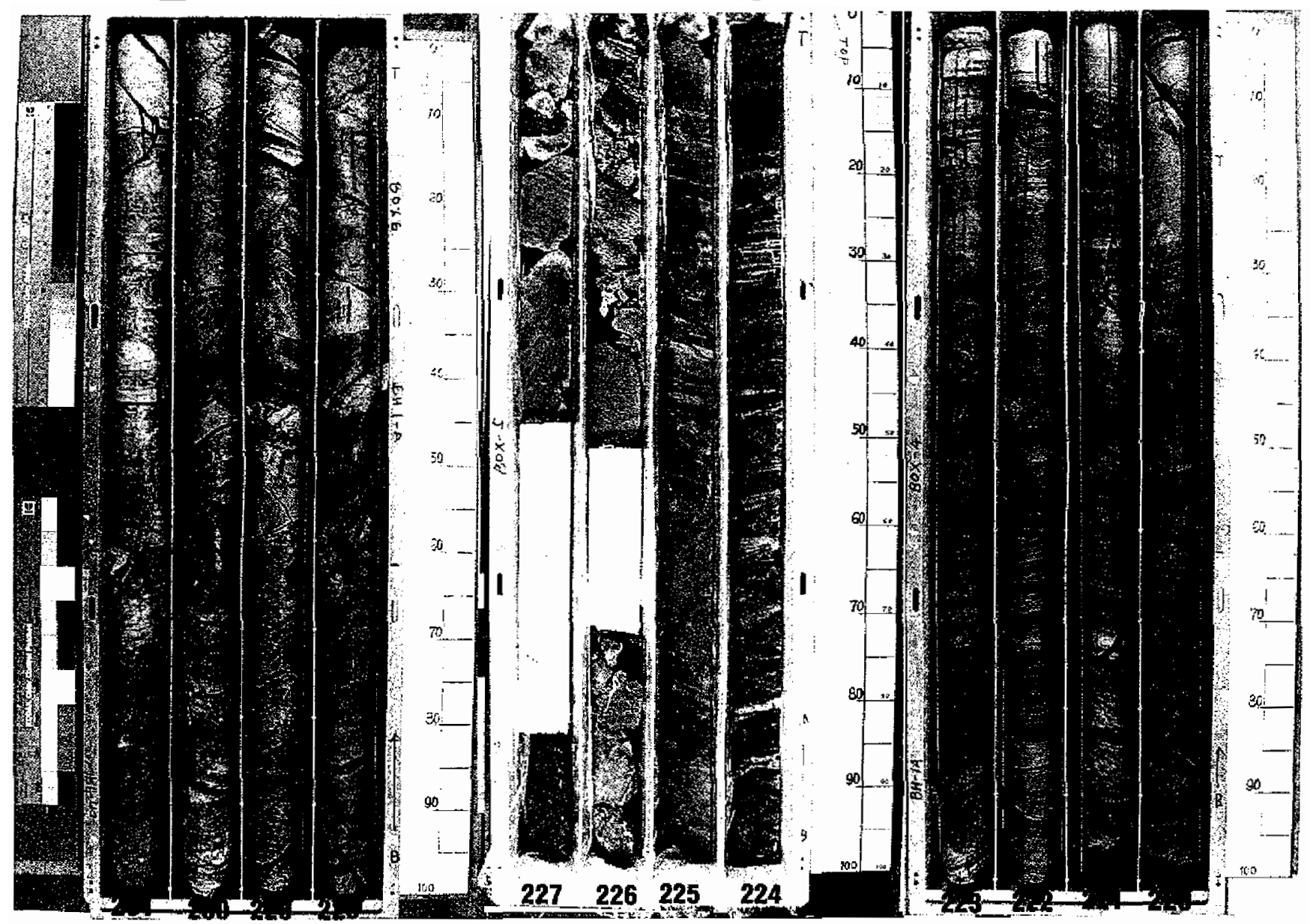

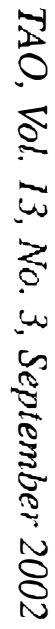

Fig. 6. Core photographs of BH-1A at 220-231m. Zone b1 is the slip zone of the Chi-Chi earthquake. Depth interval between 224.6-224.8 $\mathrm{m}$ is a gouge zone. Above 225.3 meter is the Chinshui Shale whereas below the depth of $225.3 \mathrm{~m}$ is the Kueichulin Formation (the Yutenping Sandstone Member). 


\section{BH-1A (2b2)}

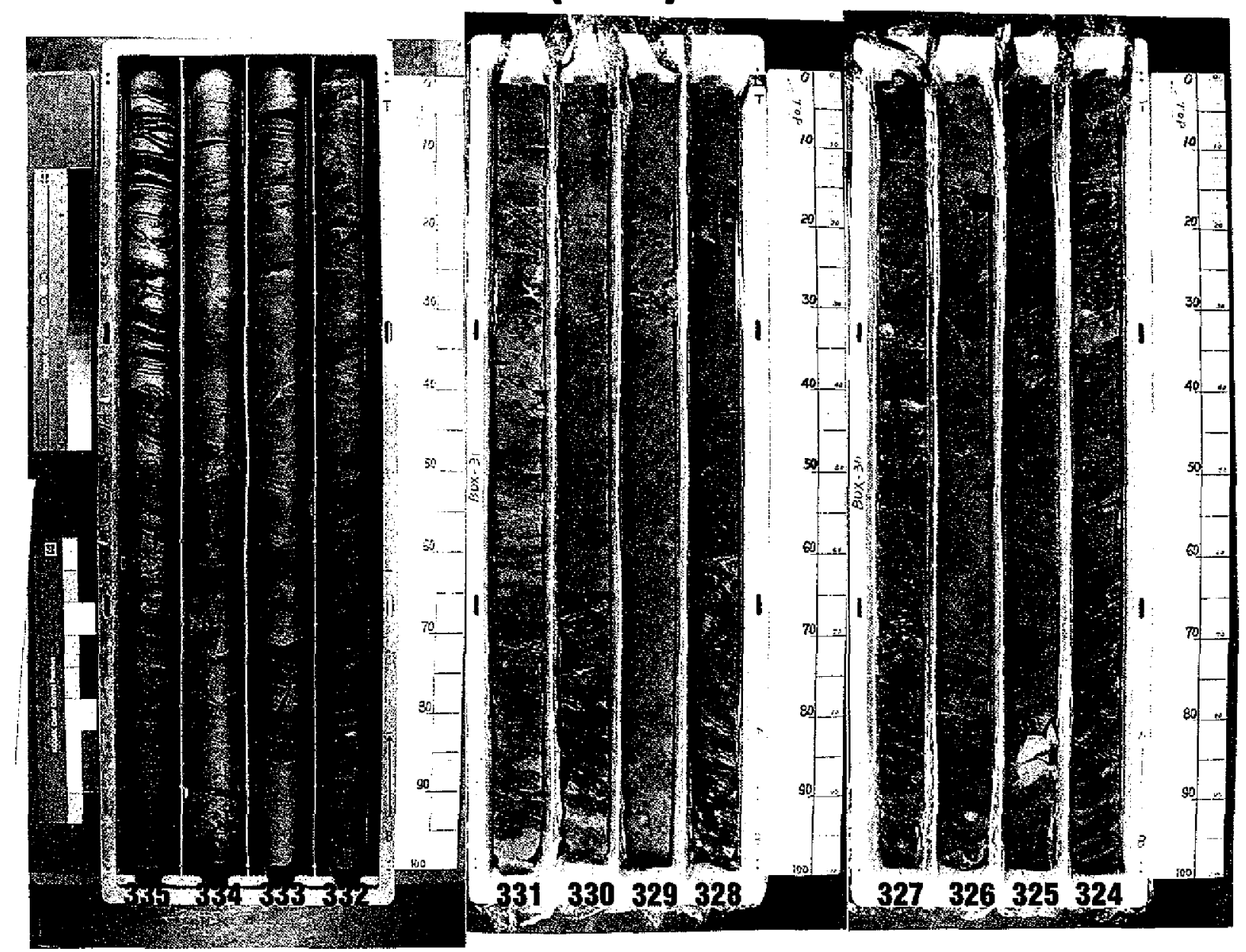

Fig. 7. Core photographs of zone b2 (324-335m) of BH-1A. Intensely brecciated shear zone is located at $328.7 \mathrm{~m}$. Note lenticular bedding at 331.6-331.9 $\mathrm{m}$ and wavy bedding at $334-335 \mathrm{~m}$. 


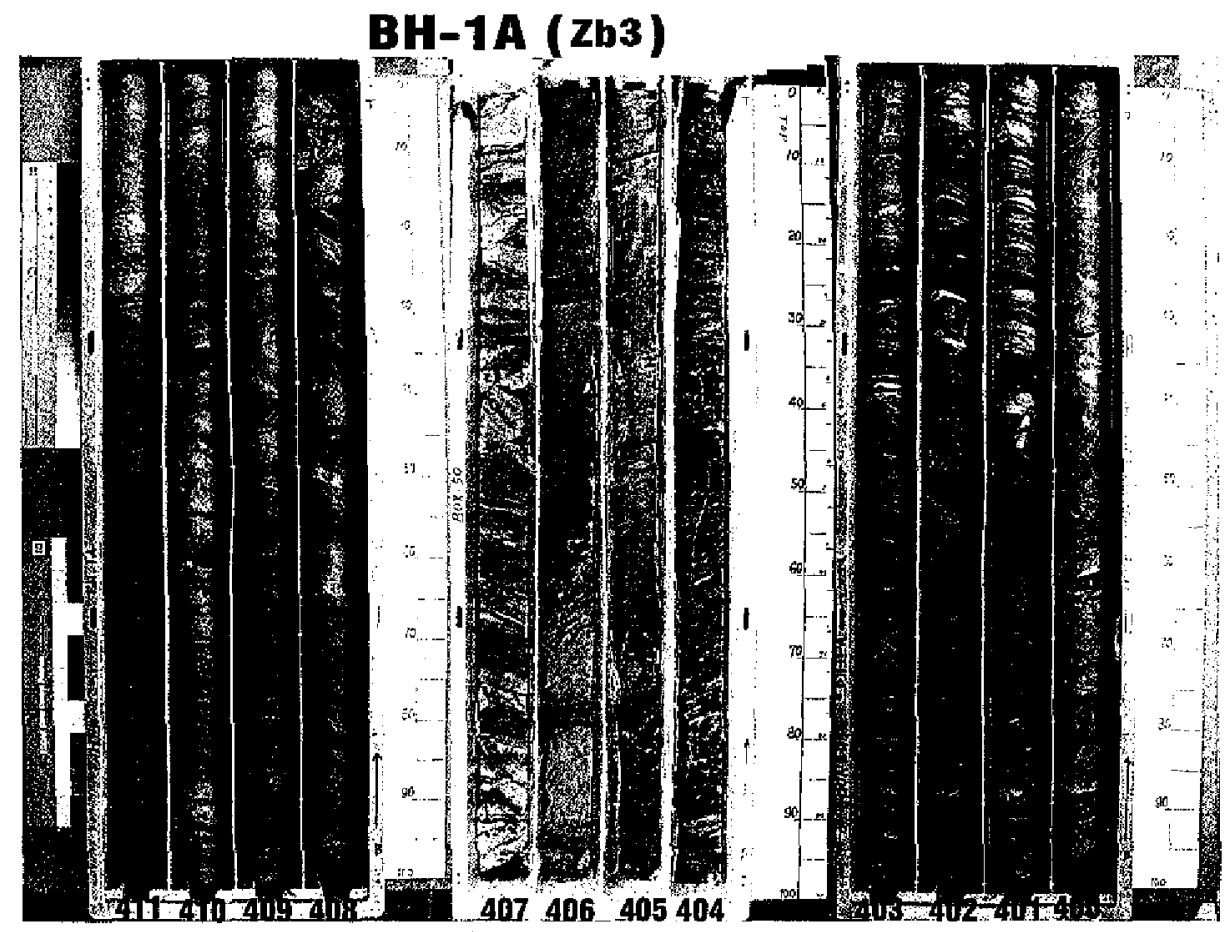

Fig. 8. Core photographs of zone b3 $(400-411 \mathrm{~m})$ of BH-1A. Foliated gouge zone appears in 405.3-405.65 m. All cores between the depth of 399-403m express tidal deposits.

the base and a coarsening upward bedsets without trough cross bedding of fluvial system. The sharp invasion of storm deposits also created several hummocky cross beddings. The Chinshui Shale is interpreted as a shallow marine deposit with occasional tidal and storm processes. It is also difficult to find the scour surface of tidal channel and coarse-grained deposits in shallow marine facies. In the succession of terrace deposit, it is possible to find that the leaching mottled mudstone in the upper part and pebble layer in the middle, whereas the paleosol, containing black carbonaceous material, can only be found at the base (Fig. 11).

\section{NANNOFOSSIL ANALYSIS AND STRATIGRAPHY}

Nannofossil biostratigraphy from cores at various depths was identified according to their assemblages (Tables 2 to 4). Samples from all three boreholes fall in the range of NN14-NN15 (Matini fossil zone, Martini 1971), which is upper Early Pliocene in age and equivalent to the Yutenping Sandstone Member and the Chinshui Shale along the Holung-Chi sections of Miaoli area, northern Taiwan. The boundary between the Chinshui Shale and the Kueichulin Formation in BH-1 borehole is located at $210.5-225.6 \mathrm{~m}$ based on the distribution richness of nannofossil (Fig. 13). Peak variation on nannofossil content in the BH-1A borehole probably originated from the change of parasequence between different delta systems within the 


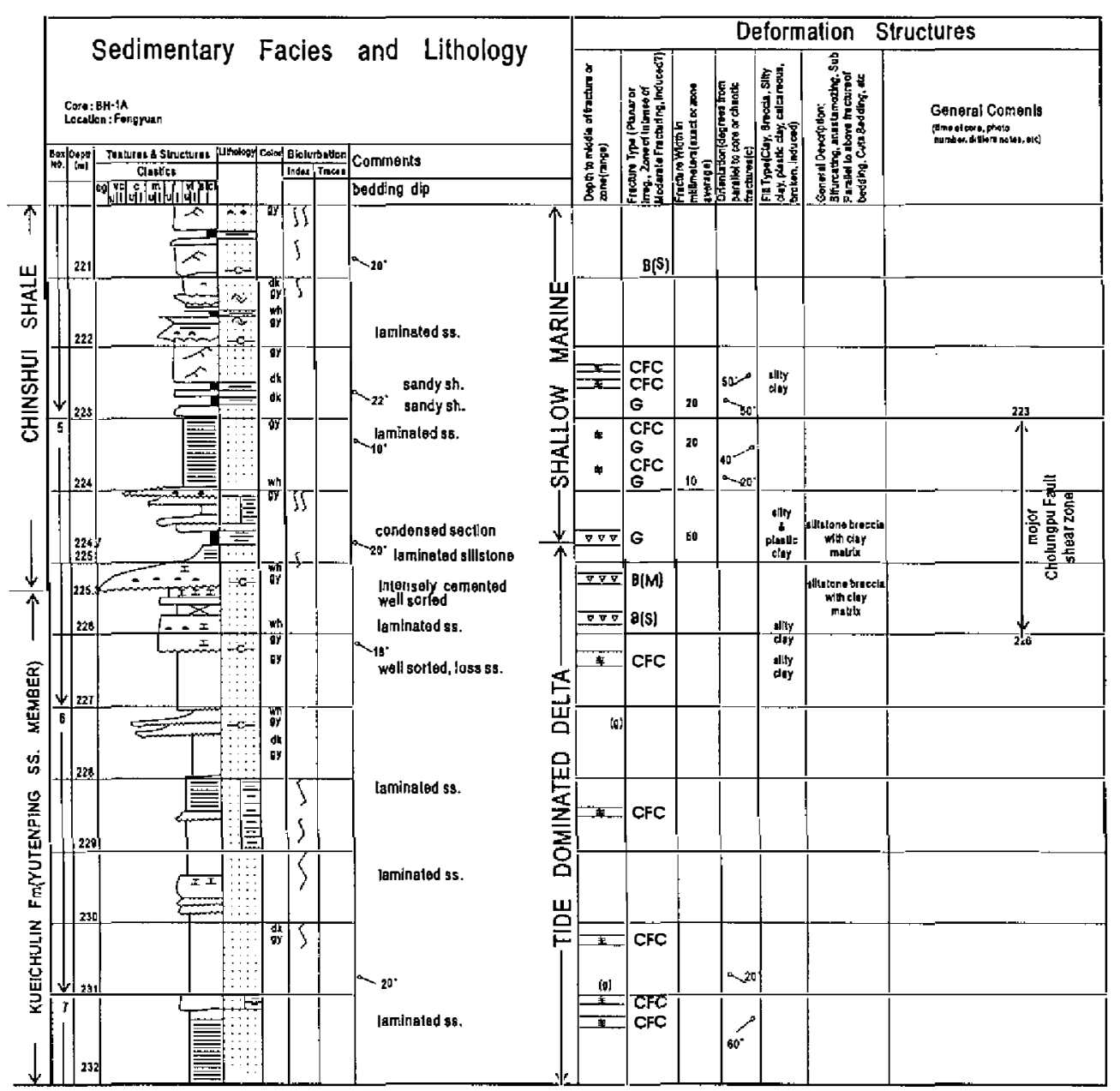

Fig. 9. Composite geologic log showing both sedimentary facies and geological structures at the sequential boundary between the Yutenping Sandstone and the Chinshui Shale.

Yutenping Sandstone (Fig. 14). In addition, the boundary between the Chinshui and the Kueichulin Formation can also be judged by lithofacies and sedimentary facies. Sedimentary processes of the Chinshui Shale and the Yutenping Sandstone in the Chuhuangkeng section along the Houlung-Chi have been studied by Covey (1984a and 1984b). Yutenping Sandstone is a tidal-delta deposit judging from the sedimentary structures. The evidence of tidal process is sharply reduced in the Chinshui Shale. In Figs. 4 and 11, the stratigraphic boundary between the Yutenping Sandstone and the Chinshui shale can be distinguished by changes in sedimentary environment and rock types. The sedimentary environment of the Yutenping Sandstone is characterized by tidal delta, whereas the Chinshui Shale is shallow marine. Lithology of the Yutenping Sandstone comprises upward coarsening tidal delta mudstone and sandstone, whereas the Chinshui Shale is an alternation of marine shale and mudstone. 


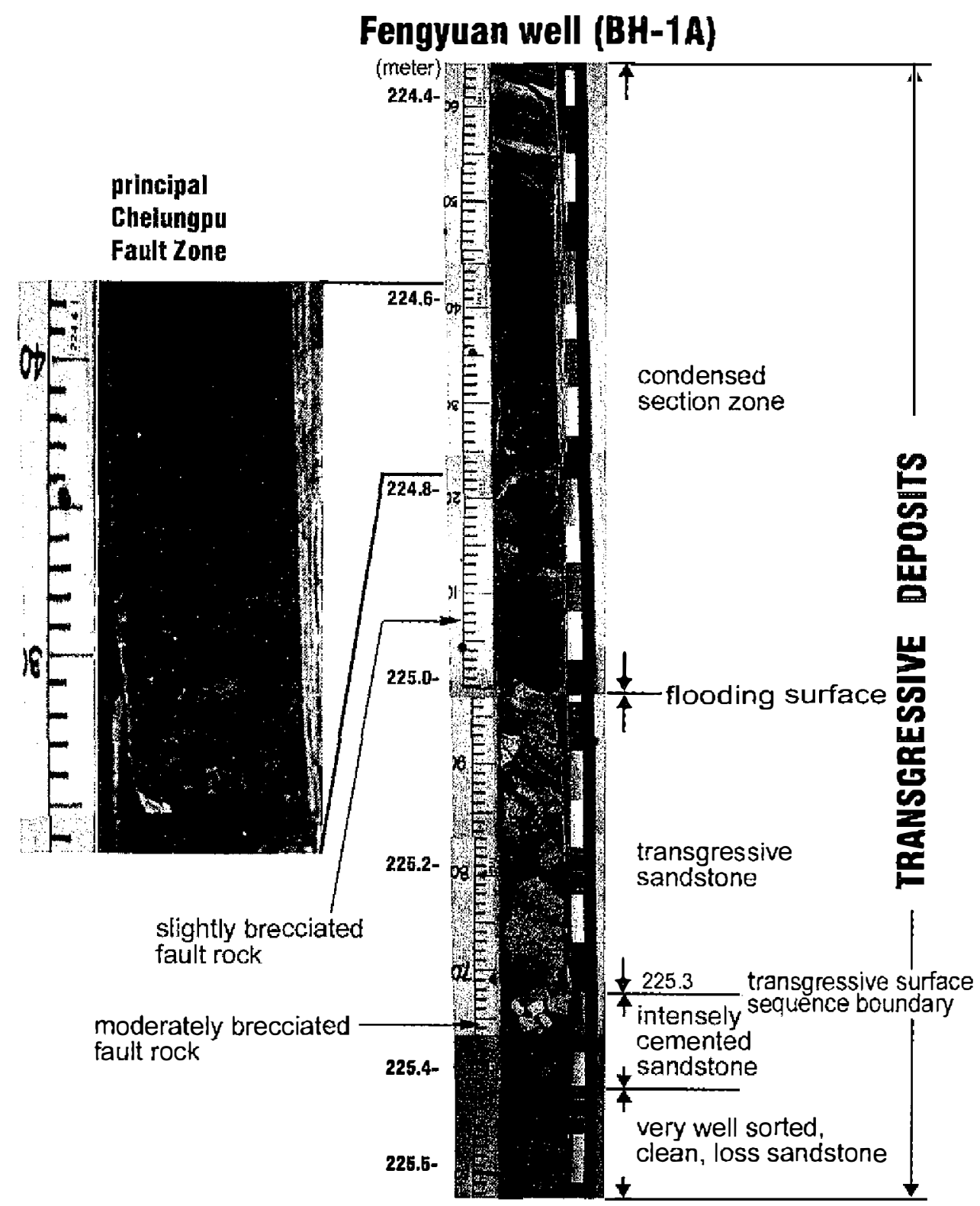

Fig. 10. Core photographs at the depth of 224.4 225.5m of BH-1 A.

\section{DEFORMATION FABRICS}

Deformation fabrics from cores indicate that rocks are deformed in brittle regime and evolved from primary sedimentary structures. Fault rocks are either breccia or gouge (Sibson 1977; Scholz 1990). To classify the sheared fabrics, we established various patterns of shear zones based on the texture and degrees of deformation (Table 5). The brecciated fabrics can be 
Nantou Well(CLF-2)

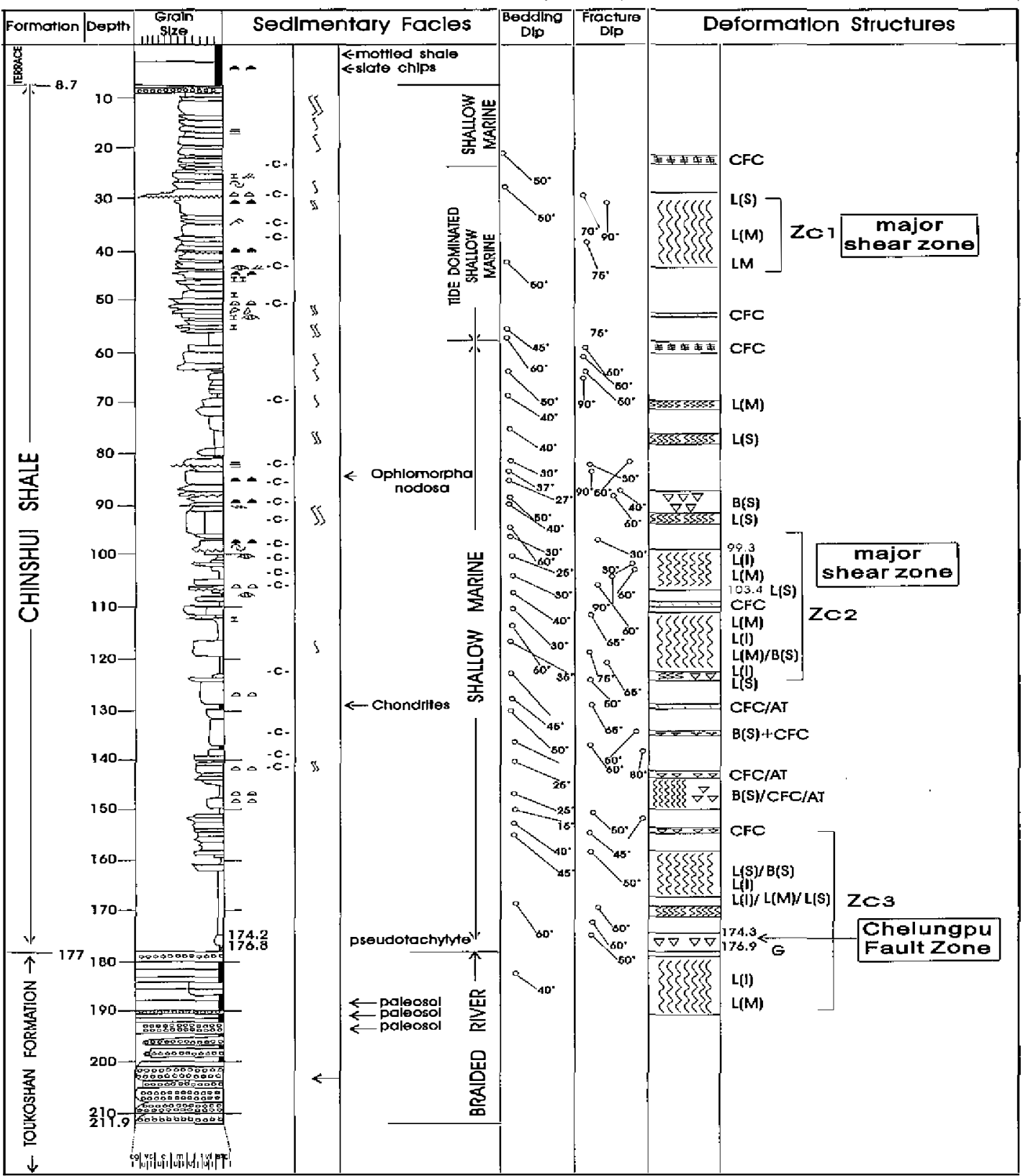

Fig. 11. Geological column of Nantou well (CLF-2). 
CLF-2 ( Zc3, Chelungpu Fault Zone)

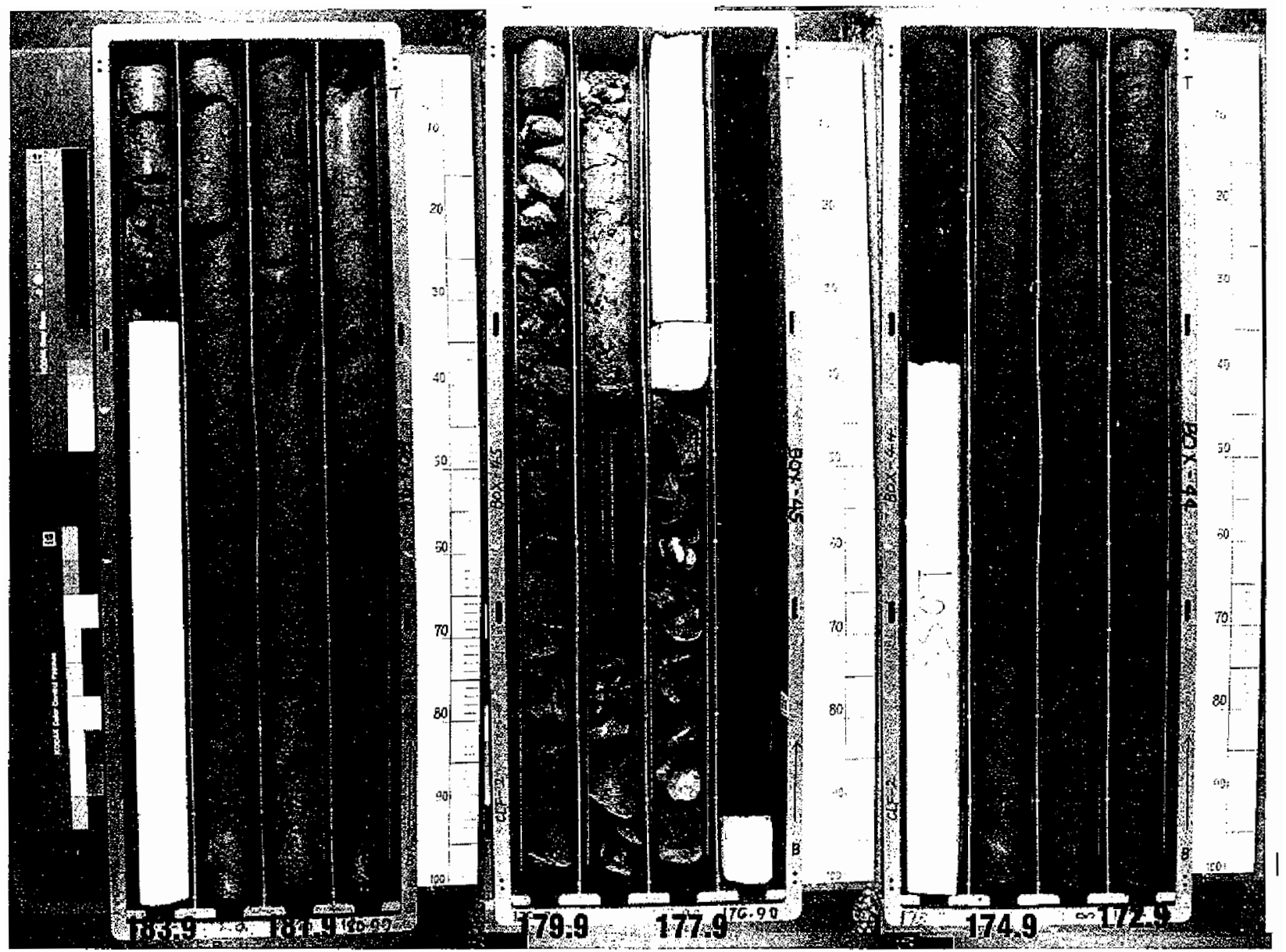

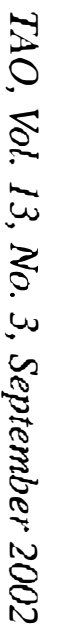

Fig. 12. Core Photographs of 172.9-183.9 $\mathrm{m}$ in CLF-2. Zone C3 is the slip zone of the Chi-Chi earthquake. Black sandstone contains pseudotachylyte (Otsuki and Mozawa 2001). The underlying yellowish mudstone and conglomerate are Toukoshan Formation, which is overlain by the darkish Chinshui Shale. 
Table 2. Nannofossil analysis of Fengyuan well (BH-1).

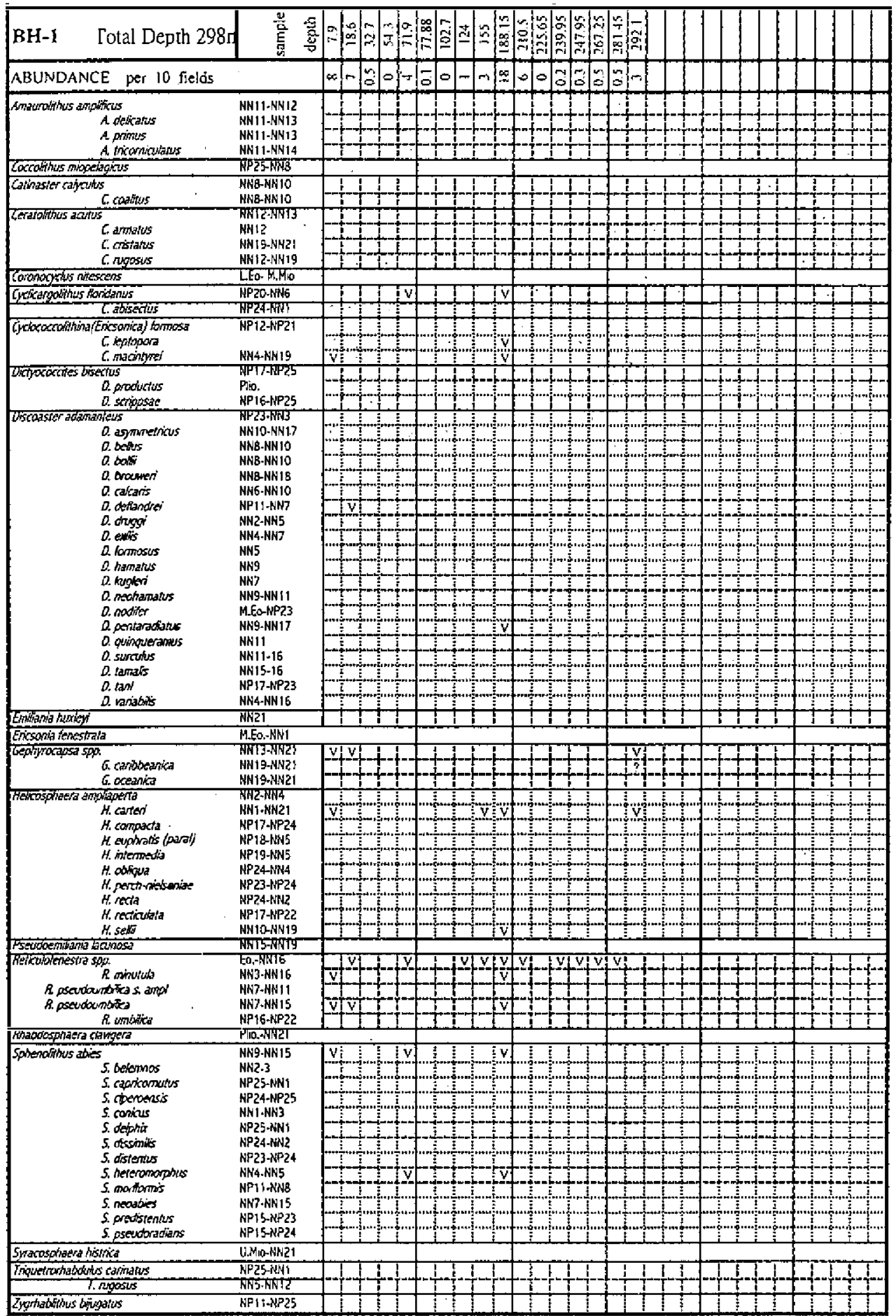


Table 3. Nannofossil analysis of Fengyuan well (BH-1A).

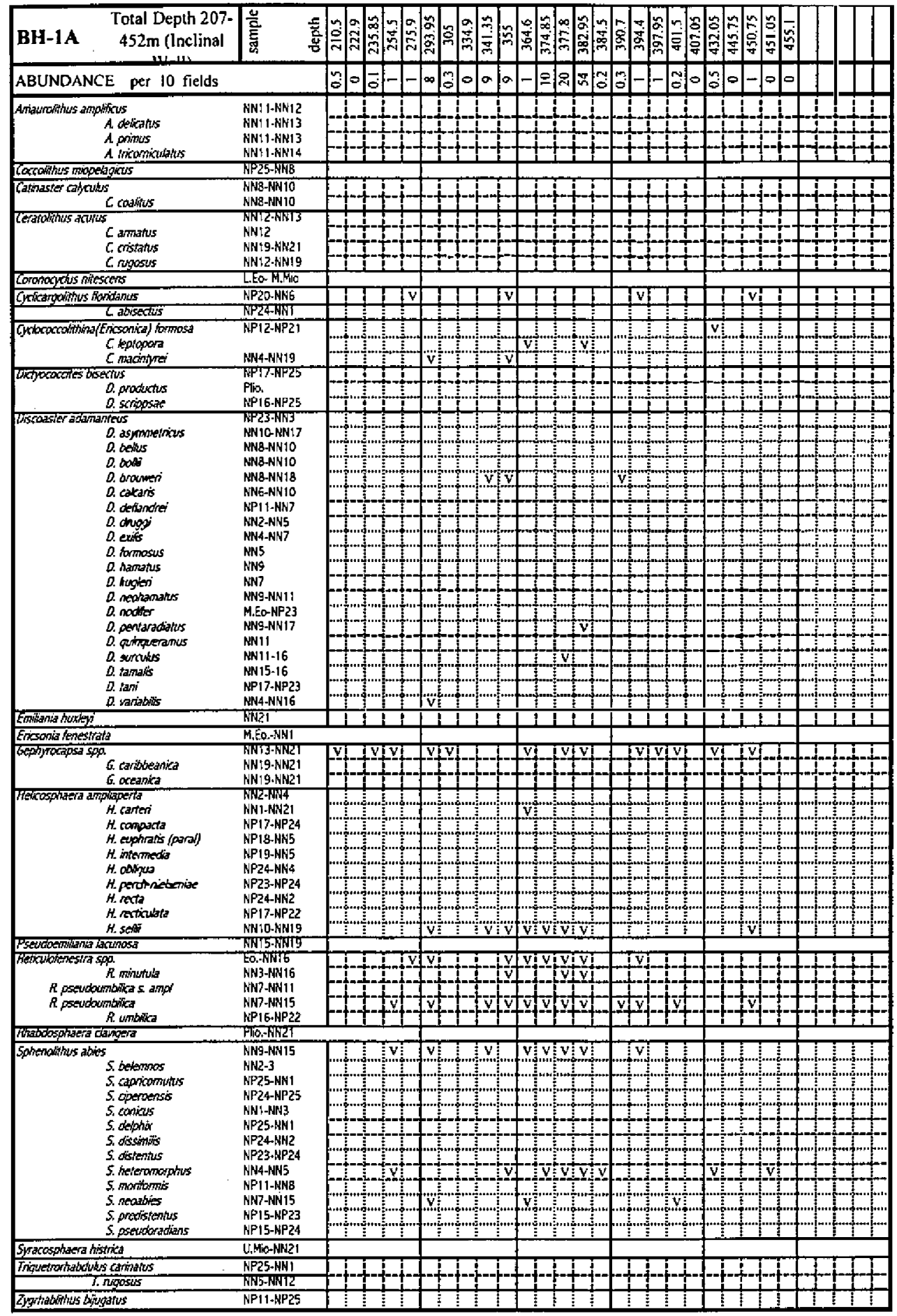


Table 4. Nannofossil analysis of Nantou well (CLF-2).

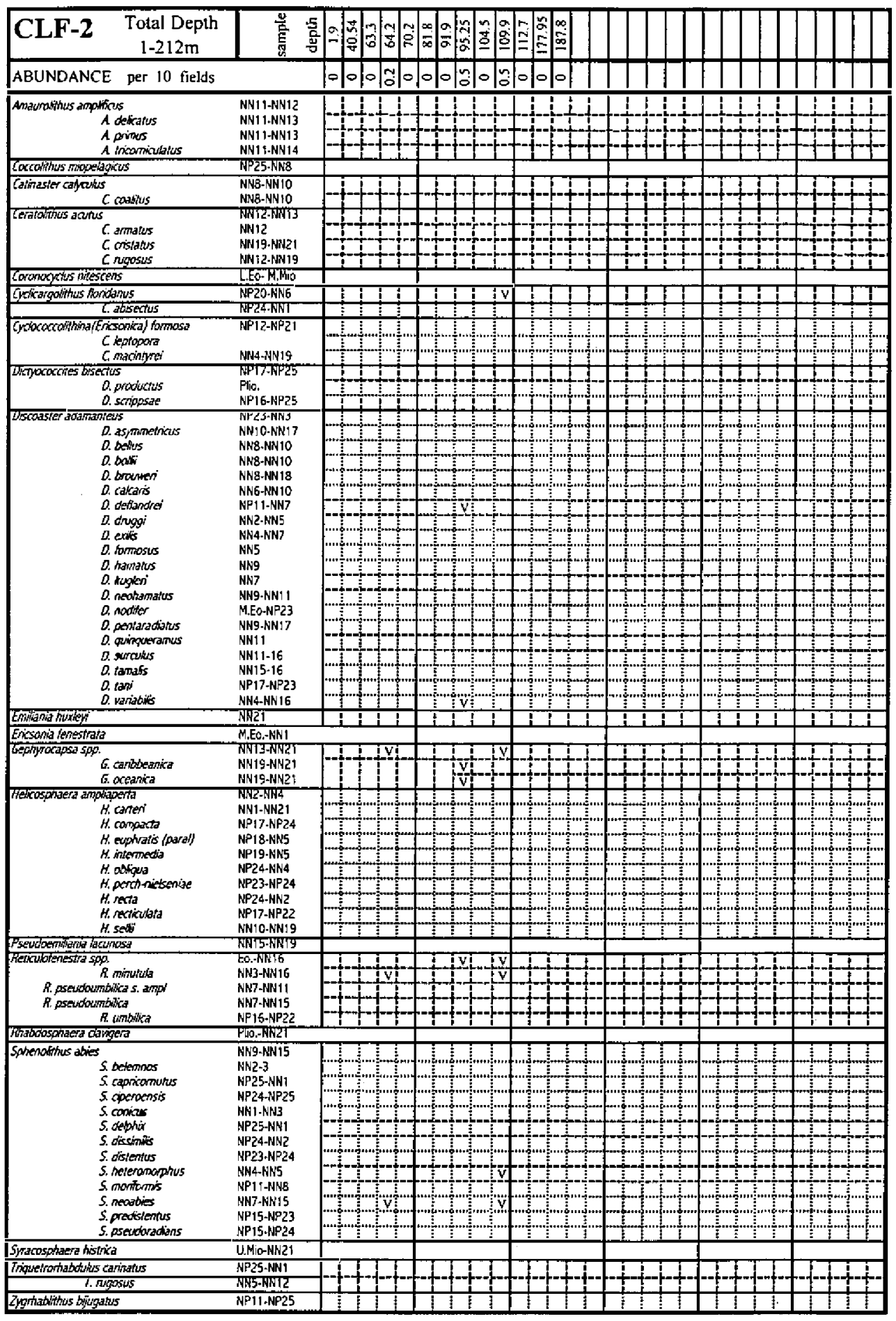




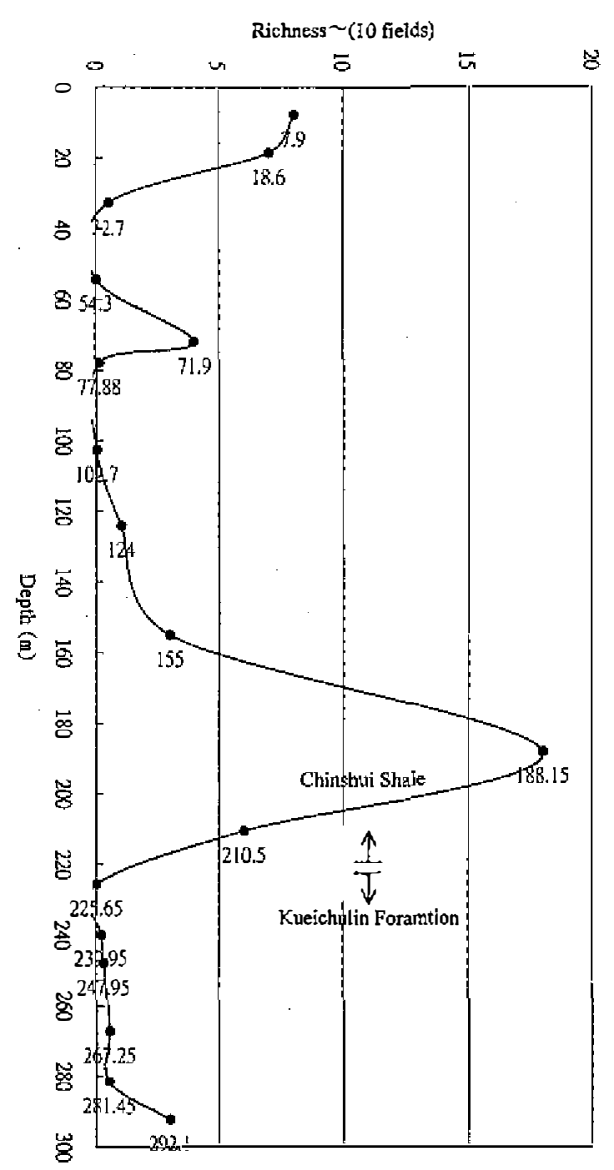

Fig. 13. Nannofossil content in the Fengyuan well (BH-1) and the possible boundary between the Kueichulin Formation and Chinshui Shale.

subdivided into five classes. Exemplified photographs of these fabrics are illustrated in Fig. 15.

Shearing under brittle regime, sandstone beds can be considered as stiff layers, whereas mudstone layers are soft. Therefore, sandstone beds are easily grinded into angular breccia and suspended in the matrix of small fragments during shearing processes. As grain-size reduction continued, fault gouge developed when the amount of visible fragments is less than $30 \%$ of the rock mass (Sibson 1977; Scholz 1990). Fault gouge is a dark colored band and may be foliated if sheared fabrics rotate parallel or sub-parallel to shear directions. Secondary shear within shear zones are well documented in previous studies (Logan et al. 1981; Rutter et al. 1986). Their studies show that cleavage density and thickness of gouge are related to the amount of slip.

Brittle shear zone is formed by brittle deformation mechanisms, whereas ductile shear zone is characterized by foliation and lineation structures that often developed in metamorphic processes. Rocks of the Fengyuan and Nantou wells are deformed under brittle regime, but the generation of foliated fabrics should be related to ductile flow of mudstone. Generally speaking, the classification of foliation in this study is based on the distortion degree of parallel fabrics in beds. Three subdivided patterns are listed in Table 5. Exemplified photographs of these foli- 


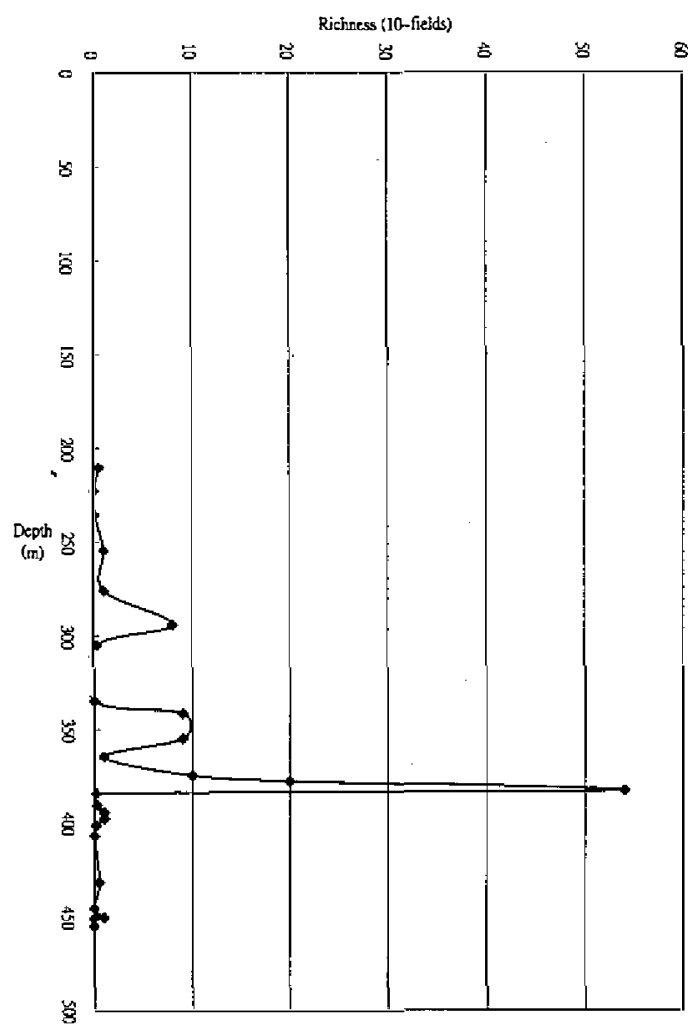

Fig. 14. Nannofossil content of Fengyuan well (BH$1 \mathrm{~A})$.

ated fabrics are also illustrasted in Fig. 15. As massive mudstone or laminated mudstone gradually change into alternation of sandstone and shale, foliation is less developed and gradually replaced by random fabrics of breccia. As the intensity of brecciation decreases, slightly brecciated pattern developed (Fig. 11).

In structural analysis, major shear zones are determined by features such as thick plastic gouge, and the brecciation intensity pattern of the related breccia zones decreases both upward and downward. In BH-1 borehole (Fig. 3), the Chelungpu Fault zone (Za3) is determined at 220.14-224.7 $\mathrm{m}$ by features including dark loss fine-grained sandstone or siltstone, and thick gouge. Most parts of this fault zone were not recovered by this core, so it is necessary to drill a second hole. A wide briccia zone ( $\mathrm{Za} 2$ ) between $140-180 \mathrm{~m}$ is correlated to the tidal dominated delta facies in the Chinshui Shale. It could be deduced that the tidal beddings can be used as slipping plains easily because of the lubricant pure mudstone deposited during the ebb tide in the nearshore area. Another major shear zone (Za1) is determined at about $20 \mathrm{~m}$ of BH-1. But brecciation intensity of this zone is less than that in the other two zones.

In $\mathrm{BH}-1 \mathrm{~A}$ borehole, three major zones $\mathrm{Zbl}, \mathrm{Zb} 2$ and $\mathrm{Zb} 3$ are determined (Fig. 4). Core photographs are respectively shown in Figs. 6,7 and 8. The Chelungpu Fault zone (Zb1) is determined at 210-235 m. For BH-1 A borehole, it could make an tentative interpretation about the causal relationship between the transgressive deposits (Figs. 6, 9 and 10) and the occurrence of Chelungpu Fault zone. The trangressive sandstone plays as an aquifer, and the intensely cemented sandstone is the impermeable barrier, whereas the condensed section offers 
Table 5. Classification of sedimentary fault rocks.

\begin{tabular}{|c|c|c|c|}
\hline Symbol & Pattern & Deformation Features & Example \\
\hline $\mathrm{CFC}$ & $\begin{array}{l}\text { Cracks filled } \\
\text { with clay }\end{array}$ & $\begin{array}{l}\text { Crack filled with clay mineral, especially in the } \\
\text { alternation of sandstone and shale. }\end{array}$ & Fig. 15a \\
\hline$B(S)$ & $\begin{array}{l}\text { Slightly } \\
\text { brecciated }\end{array}$ & $\begin{array}{l}\text { Size of breccia blocks, or coarse grains are almost } \\
\text { equivalent to bed thickness and discreted each } \\
\text { other and can't keep parallel form to original } \\
\text { bedding planes. }\end{array}$ & Fig. 15b \\
\hline $\mathrm{B}(\mathrm{M})$ & $\begin{array}{l}\text { Moderately } \\
\text { brecciated }\end{array}$ & $\begin{array}{l}\text { Partly breccia blocks of host rock are abrasive into } \\
\text { finer grains and show mixture of coarser and finer } \\
\text { grains wheras the diameter of fine-grained breccia } \\
\text { is much less than the bed thickness of host rock }\end{array}$ & Fig. 15c \\
\hline $\mathrm{B}(\mathrm{I})$ & $\begin{array}{l}\text { Intensely } \\
\text { brecciated }\end{array}$ & $\begin{array}{l}\text { Grain size of breccia is much less than the bed } \\
\text { thickness of host rock }\end{array}$ & Fig. $15 \mathrm{~d}$ \\
\hline G & Gouge & $\begin{array}{l}\text { Darkish gray color, or with plastic properties, and } \\
\text { visible fragments less than } 30 \%\end{array}$ & $\begin{array}{l}\text { Fig. } 15 \mathrm{e} \\
\text { Fig. } 15 \mathrm{f}\end{array}$ \\
\hline $\mathrm{L}(\mathrm{S})$ & Slightly foliated & $\begin{array}{l}\text { Beds of host rock are slightly discreted and almost } \\
\text { keep parallel bedform with nearby bedsets }\end{array}$ & Fig. $15 \mathrm{~g}$ \\
\hline $\mathrm{L}(\mathrm{M})$ & $\begin{array}{l}\text { Moderately } \\
\text { foliated }\end{array}$ & $\begin{array}{l}\text { Beds of host rock are discreted and can't keep } \\
\text { parallel bedform with nearby bedsets }\end{array}$ & Fig. 15h \\
\hline $\mathrm{L}(\mathrm{I})$ & $\begin{array}{l}\text { Intensely } \\
\text { foliated }\end{array}$ & $\begin{array}{l}\text { Beds of host rock are completely discreted and } \\
\text { highly contorted and difficult to find the original } \\
\text { depositional structure and bedform }\end{array}$ & Fig. $15 \mathrm{i}$ \\
\hline AT & $\begin{array}{l}\text { Anastomosing } \\
\text { structure }\end{array}$ & $\begin{array}{l}\text { Divergent and net-like deformed structure probably } \\
\text { produced by the quick dehydration of water, or } \\
\text { fluids }\end{array}$ & Fig. $15 \mathrm{j}$ \\
\hline
\end{tabular}

the lubricant pure shale which is possibably the best place for displacement of the Chelungpu Fault during shearing (Fig. 9). The interval $290-340 \mathrm{~m}$ of BH-1A hole is a major shear zone ( $\mathrm{Zb} 2)$ that matched with the prodelta mudstone facies with lamination, lenticular bedding and wavy bedding (Fig. 7). The gouge zone bounded by two intensely brecciated unit is at 327.8$329.8 \mathrm{~m}$ (Fig. 4). Another major shear zone ( $\mathrm{Zb3}$ ) of BH-1A is determined at $380-430 \mathrm{~m}$. Foliated gouge zone is banded at $404.8-405.7 \mathrm{~m}$ (Figs. 4 and 8). The above two major shear zones matched with the parasequence boundaries of tide dominated delta facies within the 


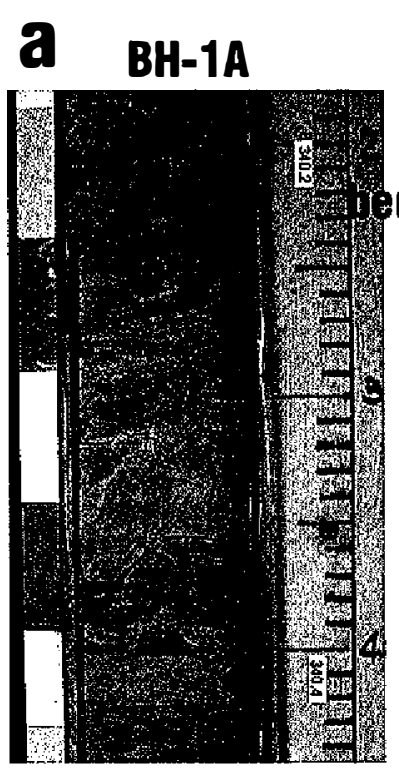

CFC

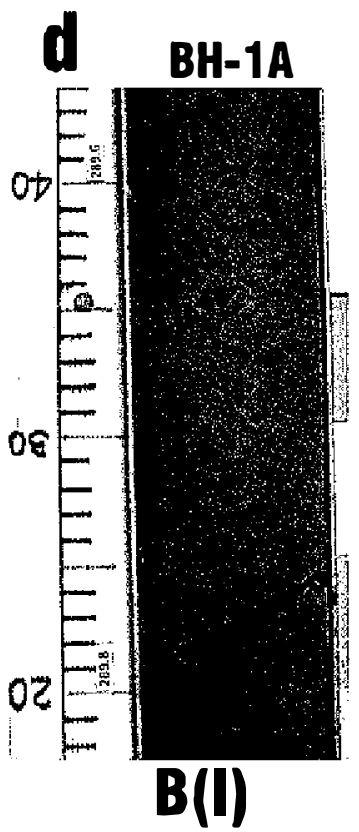

b BH-1A

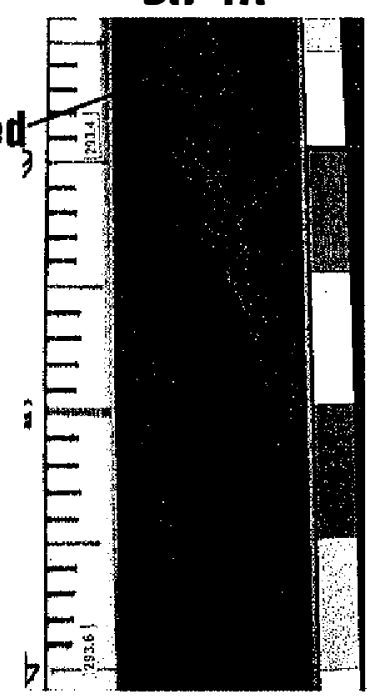

$\mathbf{B}(\mathbf{S})$

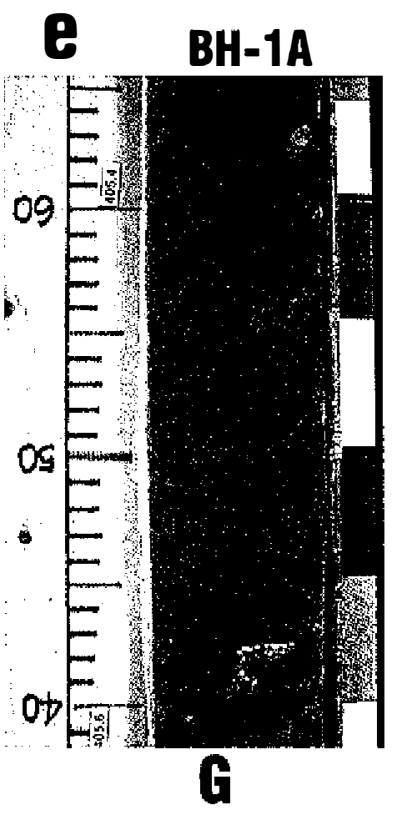

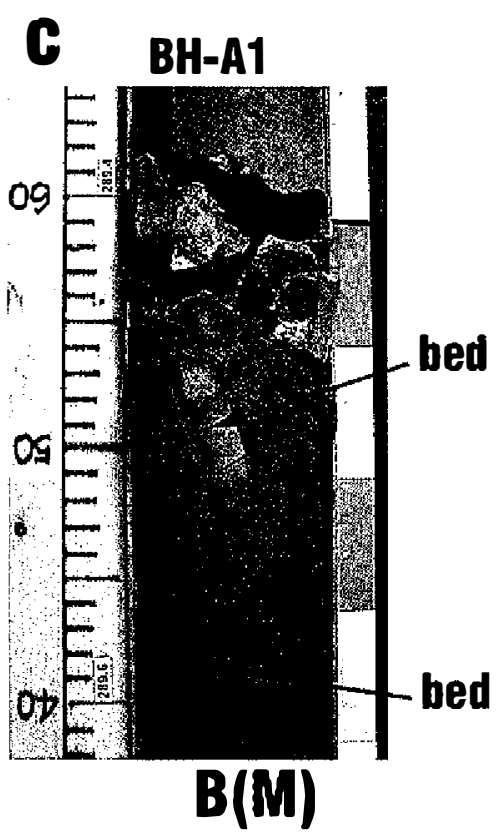
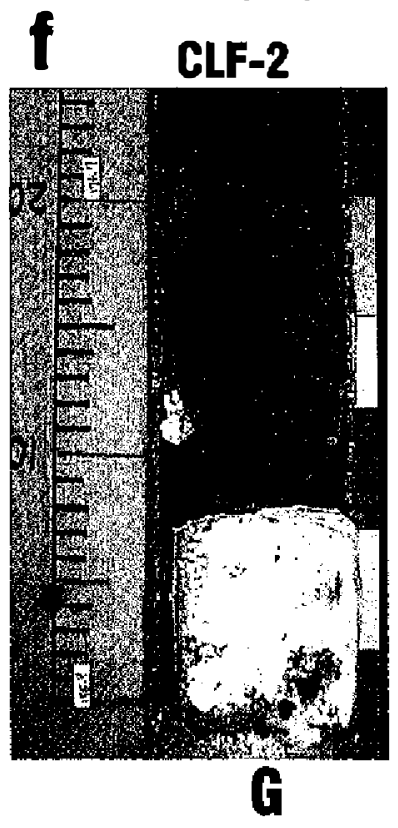

Fig. 15. Core photographs showing various deformation structures within fault zone. a) cracks filled with clays $(\mathrm{CFC})$, b) slightly brecciated $(\mathrm{B}(\mathrm{S})), \mathrm{c})$ moderately brecciated $(B(M))$, d) intensely brecciated $(B(I))$, e) Gouge $(G)$ with shear foliation, $f$ ) Gouge $(G)$ with random-distributed siltstone (white material is plastics), g) slightly foliated $\mathrm{L}(\mathrm{S}), \mathrm{h}$ ) moderately foliated $\mathrm{L}(\mathrm{M}), \mathrm{i}$ ) intensely foliated $\mathrm{L}(\mathrm{I}), \mathrm{j})$ anastomosing structure (AT). 

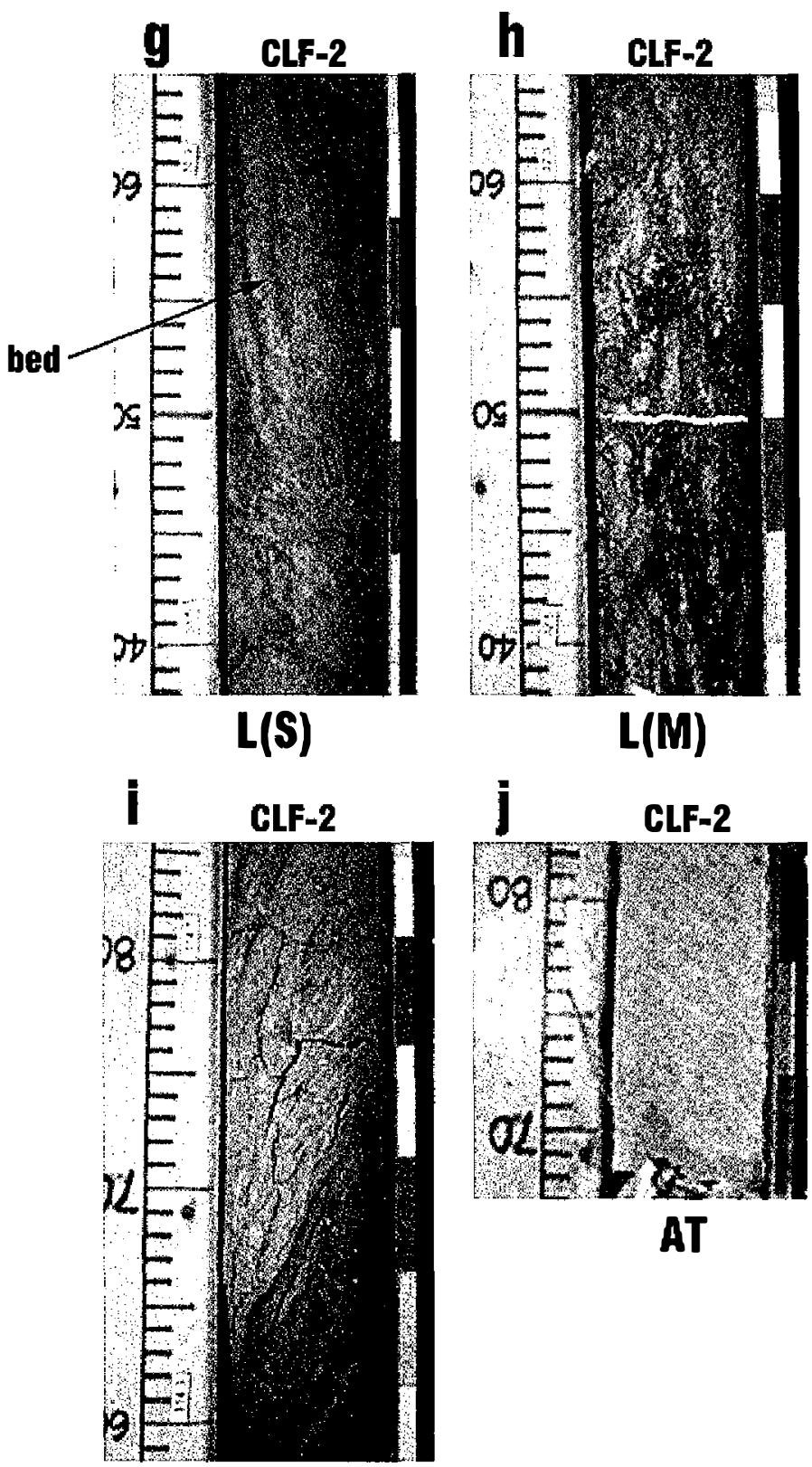

L(I)

(Fig. 15. continued)

Yutenping Sandstone member. Generally speaking, the major shear zones in BH-1A are characterized by brecciatedly deformed structure with some small parts of foliated shear structures.

The apparent bedding of $\mathrm{BH}-1 \mathrm{~A}$ dips between $17-40^{\circ}$, whereas the apparent dip of the undeformed parts of footwall of the Chelungpu Fault zone is between $15-30^{\circ}$, and $15-17^{\circ}$ for 
less deformed segments (Fig. 4). When we corrected the dips of the cored strata of $\mathrm{BH}-1 \mathrm{~A}$, the true attitude of slip bedding is about $21^{\circ}$, and the fracture elements are revealed as conjugate Rl, and X in Ridel shear model (Fig. 5).

In the Nantou well, the true dip of the pebble layer in the Toukoshan Formation in the footwall of the Chelungpu Fault zone is $40^{\circ}$, and that from the stable segment of top Chinshui Shale in the hanging wall is $50^{\circ}$. The dips of other parts of the well seem to be variable. Fractures near the Chelungpu Fault zone are almost parallel to bedding (Fig. 11). Three major shear zones including Zc1, Zc2 and Zc3 determined from the Nantou Well (CLF-2) distribute at depths of 30-45 m, 95-125 m, and 155-190 m, respectively (Fig.11). A distinguished section of darkish gray siltstone found at $174.3-176.9 \mathrm{~m}$ in zone $\mathrm{c} 3$ of the Nantou well (CLF-2) is termed as pseudotachylyte zone, which contains insufficiently digested host rocks (i.e., siltstone; Fig.12). The constituent of these black sandstone is still under microscopic observation. Recently, Otsuki and Monzawa (2001) has verified that pseudotachylyte in the Nantou well was generated at deeper part (about $250 \mathrm{~m}$ ) and has been emplaced to present shallow depth of $175 \mathrm{~m}$. The psedudotachylyte zone is interpreted to be generated under very high strain rate during the seismic shock of Chi-Chi earthquake so this zone is considered as the true Chelungpu Fault. Furthermore, the Chelungpu Fault zone is surrounded by intensely foliated deformation structures. The other major shear zone (Zc2) at depth 95-125 m of CLF-2 is characterized by intensely foliated deformation structures (Fig. 11). At the two edges of this zone, slight brecciated structures could be found. Another major shear zone (Zcl) of CLF-2 at 30-45 m is significant with moderately foliated deformation sucture (Fig. 11). In general, foliated deformation structures are the main features in the Nantou Well. Anastomosing structures of quick dehydration occurred between $\mathrm{Zc} 3$ and $\mathrm{Zc} 2$ also revealed that the lower part of the geological

Table 6. Summary of stratigraphic and deformation characteristics in Fenguan and Nantou wells.

\begin{tabular}{|c|c|c|c|c|}
\hline Well & Formation & Sedimentary Facies & Lithology & Deformation Structures \\
\hline \multirow{3}{*}{$\begin{array}{l}\text { Fengyuan Well } \\
\text { (including BH- } 1 \& \\
\text { BH-l A boreholes) }\end{array}$} & Terrace & $\begin{array}{l}\text { Paleosol,leacling } \\
\text { soil }\end{array}$ & $\begin{array}{l}\text { Soil, mudstone, pebble } \\
\text { etc. }\end{array}$ & \\
\hline & Chinshui Shale & $\begin{array}{l}\text { Shallow marine } \\
\text { with tidal process, } \\
\text { oscasionally }\end{array}$ & $\begin{array}{l}\text { Silstone,mudstone, } \\
\text { fine-grained } \\
\text { sandstone settings }\end{array}$ & Bedding brecciated shear zone with $R 1 \& X$ fractures \\
\hline & Kueichulin & $\begin{array}{l}\text { Tide dominated } \\
\text { delta }\end{array}$ & $\begin{array}{l}\text { Coarsening upward } \\
\text { assemblages }\end{array}$ & $\begin{array}{l}\text { 1. Bedding brecciated shear zone with RI\&X fractures } \\
\text { 2. Major shear zones are matched with sequence and } \\
\text { parasequence boundaries }\end{array}$ \\
\hline \multirow{3}{*}{$\begin{array}{l}\text { Nantou Well } \\
\text { (CLF-2) }\end{array}$} & Terrace & Paleosol & $\begin{array}{l}\text { Yellowish mud, } \\
\text { Layering pebbles }\end{array}$ & \\
\hline & Chinshui Shale & $\begin{array}{l}\text { Shallow marine } \\
\text { withtidal process, } \\
\text { occasionally }\end{array}$ & $\begin{array}{l}\text { Mudstone, siltstone, } \\
\text { fine-grained } \\
\text { sandstones }\end{array}$ & $\begin{array}{l}\text { 1. Foliated fabrics and part of transitional pattern between } \\
\text { typical brecciaed and foliation structure with } P \& X \\
\text { fractures } \\
\text { 2. Pseudotachylyte }\end{array}$ \\
\hline & Toukoshan & $\begin{array}{l}\text { Braided fluvial } \\
\text { system }\end{array}$ & $\begin{array}{l}\text { Conglomerate, } \\
\text { mudstone, pebbles }\end{array}$ & $L_{\text {Foliated fabrics }}^{\text {Chelungpu Fault }}$ \\
\hline
\end{tabular}


column in the Nantou well is highly with saturated water.

\section{DISCUSSION}

Results of stratigraphic and deformation features are summarized in Table 6. The Chinshui Shale is composed of siltstone in the Fengyuan well and mudstone in the Nantou well. The Fengyuan well is characterized by brecciated fabrics, whereas the Nantou well is mainly foliated fabrics with a mixture of brecciation and foliation. The appearance of pseudotachylyte is a unique feature in the Nantou well.

Material in a fault zone is affected by several factors, such as rock type, strain rate, physical environments, and duration of faulting (Davis and Reynolds1996). In sedimentary rocks, the heterogeneity in lithology could play an important factor. The contrasting style of deformation fabrics between Fengyuan and Nantou wells can be attributable to the difference in lithology and sedimentary facies.

Major shear zones in the Fengyuan well are coincident with sequence or parasequence boundaries. It is possible that the prodelta mud or marine mudstone would be the weak zone for slip during the Chi-Chi earthquake. The ransgressive porous sandstone can be good aquifer, and the condensed section is a lubricant layer to localize Chelungpu Fault zone. Yuan et al. (1987) pointed out that the occurrence of overpressure zones in the subsurface in southwestern Taiwan is highly related to the sedimentary cycles. It is unclear if the slip zone occured at the sequence or parasequence boundary, but those distinct depositional features of sequential boundaries, rather than the other part of the same successive column, would provide good conditions for the development of overpressure and slip zones. Obviously, the sequence boundary is indicated by the abrupt change in lithology, sedimentary process and depositional regime for the whole geologic column.

Secondary shear, such as R1, R2, S, T, and Y (or P foliation), can develop within major shear zones (Logan et al. 1979; Rutter et al. 1986). Owing from continuous shearing process or overprinting at various directions from seismic events, these secondary elements would become reprinted or redeformed, making it difficult to reserve their original geometry, and thus be replaced by breccia fabrics of different orientation. At the edges of shear zones, we still could observe simple rupture associations as referring to shear model and deduced from data analysis on beddings within these two wells. Rupture elements of theFengyuan well are characterized by R1 and X fractures, whereas those of the Nantou wells are P and X fractures.

\section{CONCLUSIONS}

The purpose of this paper is to construct the successive stratigraphic columns of lithofacies, sedimentary facies, and deformation fabrics of the Chelungpu Fault zone from Fengyuan and Nantou wells. The deformed structure of the Fengyuan well is dominated by brecciated shear zones, whereas foliated shear zones and local alternation of breccia and foliation are developed in the Nantou well. The Chinshui Shale in the Fengyuan well is dominated by siltstone, but marine mudstone in the Nantou well. The Toukoshan Formation in the Nantou well may act as a water conduit and thus cause strain weakening of the Chelungpu Fault zone. 
Based on the analysis of biostratigraphy, richness distribution of nannofossils in the Fengyuan well (BH-1) shows a sharp stratigraphic boundary at a depth of $220 \mathrm{~m}$. This depth corresponds to the stratigraphic boundary and the change of sedimentary environments between the Kueichulin Formation (Yutenping Sandstone member) and the Chinshui Shale. The Yutenping Sandstone deposit in tide-dominated environments whereas the Chinshui shale is in shallow marine under some tidal and storm processes. The sequence and parasequence boundaries related to the change of lithology are the weak planes of the slip of the Chelungpu Fault.

Acknowledgements Authors are very grateful to Dr. K. A. Lin, director of Exploration and Development Research Institute (EDRI), W. W. Mei, M. H. Wang, H. H. Ting, C. T. Tsai, W. B. Sue, R. Y. Hsieu, Y. L. Wu, C. J. Hsu, H. Y. Chang at EDRI and C. B. Lu, T. H. Chen at National Central University for their support and help with this study. This study benefits from discussion with Dr. M. L. Lin at Department of Civil Engineering, National Taiwan University.

\section{REFERENCES}

Ando, M., Y. B. Tsai, M. Zoback, K. Suyehiro, H. Ito, J. Mori, and H. Tanaka, 2001: Drilling the seismogenic zone of the Chelungpu Fault, Taiwan: Investigating physics of faulting for a recent large earthquake. ICDP Workshop on Drilling the Chelungpu Fault, Taipei.

Covey, M., 1984a: Sedimentary and tectonic evolution of the western Taiwan Foredeep. unpublished Ph.D. thesis, Princeton University, 152pp.

Covey, M., 1984b: Lithofacies analysis and Basin Resconswuction, Plio-Pleistocene western Taiwan Foredeep. Petrol. Geol. Taiwan, 20, 53-83.

Davis, G.H., and S. J. Reynolds, 1996: Structural Geology of Rock and Regions (2nd). John Wiley and Sons, INC., 776pp.

Hung, J. H., S. T. Huang, and J. C. Wu, 2001: Lithofacies and biostratigraphy of the core from the boreholes drilled through the Chelungpu fault, ICDP Workshop on Drilling the Chelungpu Fault, San Francisco.

Logan, J. M., M. Friedman, N. G. Higgs, C. Dengo, and T. Shimanoto, 1979: Experimental studies of simulated gouge and their application to studies of natural fault zones. In: Proceedings of Conference VIII: Aanlysis of actual fault zones in bedrock: Washington, D.C., U.S. Geological Survey Open File Report 70-1239. 305-343.

Logan, J. M., N.G. Higgs, and M. Friedman, 1981: Laboratory studies on natural gouge from the U.S. Geological Survey Dry Lake Valley No. 1 well, San Andreas fault zone. In: N. L. Carten, M. Friedman, J. M. Logan, and D.W. Stearns (Eds), Mechanical Behavior of Crustal Rocks. Am. Geophys. Un. Geophys. Monogr., 24, 121-134.

Martini, E., 1971: Standard Tertiary and Quaternary calcareous nannoplankton zonation. In: A. Farinacci (Ed.), Proc. II Plank. Conf. Rome, 1970, 737-785.

Otsuki, K., and N. Monzawa, 2001: Contrasting fault rocks from two boreholes penetrating Chelungpu Fault, Taiwan: ICDP Workshop on Drilling the Chelungpu Fault, MenloPark.

Rutter, E. H., R. H. Maddock, S. H. Hall, S. H. White, 1986: Comparative microstructures of 
nautral and experimentally produced clay bearing fault gouge. Pure appl. Geophys., 24, 3-30.

Scholz, 1990: The mechanics of earthquakes and faulting: New York, Cambridge University Press, 43pp.

Sibson, 1977: Fault rocks and fault mechanisms. J. Geological Society (London), 133, 191213.

Tanaka, H., C. Y. Wang, W. M. Chen, A. Sakaguchi, K. Ujiie, M. Ando, H. Ito, and S. T. Huang, 2001: Shallow drilling into Chelungpu fault zone, ICDP Workshop on Drilling the Chelungpu Fault, Taipei.

Wang, Y. C., H. Tanaka, G. D. Chou, C. C. Chen, and J. H. Hung, 2002: Shallow reflection Seismic aiding geological drilling into the Chelungpu Fault after the 1999 Chi-chi earthquake, Taiwan. TAO, 13, 153-170.

Yuan, C. W., S. T. Huang, D. F. Chou, R. C. Wu, and T. L. Lu, 1987: A geologic study of high pore-pressure zones in southern Taiwan. CPC, Exploration and Development Research Institute, $89 \mathrm{pp}$. (in Chinese). 